\title{
The Role of Meteorological Factor in Long-Term Variability of the River Streamflow of the Territory of North of the Russian (East European) Plain
}

\author{
Rysaeva I.A. \\ Kazan Federal University, Institute of Management, Economics and Finance, Kazan, 420008, Russia \\ Dvinskikh A.P. \\ Kazan Federal University, Institute of Ecology and Geography, Kazan, 420008, Russia
}

Pratchenko O.V.

Kazan Federal University, Institute of Language, 420008, Kazan, Russia

\section{Doi:10.5901/mjss.2014.v5n24p256}

\section{Abstract}

\begin{abstract}
As is well-known, the river stream-flow as the main source of water resources, is formed and changed under the influence of climate conditions and physiographic characteristics of watershed basins. Snow storage, liquid precipitation in the period of snow-melt flood, degree of moisture of the area, etc. are the main hydro-climatic factors determining the amount of the annual river flow. On the territory under consideration, in this case the region of the North of the Russian Plain is selected as which, flow fluctuations are well-defined as a result of changes in space and time of the main forming it factors and, mainly, the meteorological factor. In this regard, the main objective of the work is to find the connection between rainfall and river flow, as well as to identify patterns of spatial and temporal changes of river flow and precipitation. During the study, the authors identified the dependencies between precipitation and the layer of the run-off in hydrological seasons. In particular, the closest connection was established between precipitation and the flow of summer-autumn period, where the correlation coefficient ( $r$ ) for posts of Soyana - Soyana, Mudyug - Patrakeevskaya is $r=0,7-0,8$, reaching $r=0,9$ (Codina - Codino). Comparison of precipitation of the winter-spring period and the spring run-off did not reveal very close connection, except the site location of Sysola - Pervomajskij (the basin of the Northern Dvina), where $r=0,86$. It is determined that during a year there are two maxima and two minima in the distribution of precipitation, while in the overland runoff they do not fully coincide with precipitation in time. Synchronous increase of share of precipitation and runoff was observed from May to July and in October, except August (precipitation) and April (run-off), where these periods did not coincide.
\end{abstract}

Keywords: Precipitation, run-off, hydrological season, gauging station.

\section{Introduction}

As is well-known, the river run-off exposed to natural and anthropogenic space-time variability, is its most important characteristic (Berezovskay et al,. 2004). As it has already been mentioned, fluctuation of the river run-off is a function of many factors, but meteorological conditions are of the greatest importance. Amount and nature of precipitation, the temperature and humidity deficit are the most important meteorological factors in terms of their influence on run-off, i.e., the river run-off is an indicator of climate, and rhythms revealed in its long-term fluctuations reflect variations of climatic characteristics (Musaelyan, 2002).

In the light of the subject of research, the authors show a special interest for the study of the flow of rivers of the Arctic basin. Specific character of the hydrological "structure" of the region under consideration - the northern part of the Russian Plain - is determined by the influence of meteorological predictors, as well as by conditions of formation of runoff flow within lowland areas. Hydrological potential of the region consists of 138000 rivers with a total length of 521200 kilometers; about $3 / 4$ of the territory is covered by water areas of the following rivers: the Northern Dvina, Pechora, Onega, Mezen. Change of long-term average annual run-off flow complies to the zonal character, and this is clearly seen in the general pattern of change of the layer of surface runoff which decreases in the direction from north to south, and in the change of the regime of water stream-flows connected with latitudinal change of the "energetic" base of geographical processes (Filenko, 1974). Earlier studies showed that in the last 60 years the average annual run-off flow of rivers of the 
Arctic basin has increased by $7 \%$, there is also an increase of the winter component of these rivers (Shiklomanov et al ,. 2007). Other authors believe that annual fluctuations of the Arctic stream-flow are the stationary process, but they also say about change of amplitude of long-term stream-flow fluctuations (Smith et al ,. 2007).

Within the region the annual precipitation as the stream-flow forming element varies from 550-600 mm (north-east) to $750-800 \mathrm{~mm}$ (south-west), and it is characterized by unevenness of precipitation in annual cycle. Maximum precipitation (65-70\%) is during the warm season, which is predetermined by the cyclonic activity in this period, minimum precipitation - on the great part of the territory - is in the period from February to March. Here the average annual air temperature is low and it decreases from the south-west $\left(+3^{\circ} \mathrm{C}\right)$ to the north-east $\left(-8^{\circ} \mathrm{C}\right)$.

\section{Methodology}

Material of long-term observations of the Northern Territorial Administration of the Federal Service for Hydrometeorology and Environmental Monitoring (Sevgidromet) of 11 hydrological stations on the sub-basins with long-term series of observations are used in this study to establish the spatial-temporal patterns of river run-off flow. Basic data on precipitation of 6 meteorological stations in the region were obtained from the official website of the Russian Research Institute of Hydro-meteorological Information - World Data Center (Obninsk) for the study period from 1995 to 2007.

Water streamflows related to the basins of the rivers Onega, Mezen, Northern Dvina, were selected as subjects of research. Weather (meteorological observing) Stations where the amount of atmospheric precipitation and air temperature are monitored, were selected on the territory of the river basins or near them (table 1).

Table 1. Watershed storage sub-basins of the rivers Onega, Mezen, Northern Dvina

\begin{tabular}{|c|c|c|c|c|}
\hline$\#$ & River basin & Hydrological station & Watershed basin area, $\mathrm{km}^{2}$ & Meteorological station \\
\hline 1 & Kena & Korovy Dvor & 5550 & Onega \\
\hline 2 & Bol. Loptuga & Butkan & 2010 & Sura \\
\hline 3 & & Vozhael & 3940 & Syktyvkar \\
\hline 4 & Kodina & Kodino & 1800 & Onega \\
\hline 5 & Mudyuga & Patrakeevskaya & 305 & Mudyug \\
\hline 6 & Soyana & Soyana & 5570 & Vologda \\
\hline 7 & Syamzhena & Syamzha & 1700 & Vologda \\
\hline 8 & Dvinitza & Kotlaksa & 869 & Syktyvkar \\
\hline 9 & Sysola & Pervomaysky & 11700 & Ust-Vym \\
\hline 10 & Vym & Vesliana & 19100 & Ust-Vym \\
\hline 11 & Yarenga & Tokhta & 4970 & \\
\hline
\end{tabular}

Available long-term data of the flow of water of the rivers under study were differentiated into the so-called hydrological seasons: winter (December-March), spring (April-June), summer-autumn (July-November). For each item the dates of hydrological seasons were individually identified from 1995 to 2007. Then the volume values $\left(\mathrm{km}^{3}\right)$ (1) and the layer of flow values $(\mathrm{mm})(2)$ were calculated by the following formulas:

$W=86400 * 10-9 * \sum^{n_{i=1}} Q_{i}(1)$,

where $\mathrm{Q}_{\mathrm{i}}$ - average daily flow of water, $\mathrm{m}^{3} \mathrm{~s}, \mathrm{n}$ - number of days in the season

$\mathrm{y}=\underline{\mathrm{W}\left(\mathrm{KM}^{3}\right)^{\star} 10^{6}}(2)$, where $\mathrm{F}-$ area of river basin $\left(\mathrm{km}^{2}\right)$

$\mathrm{F}$

For all meteorological stations the annual, annual average and monthly average amount of precipitation, seasonal maximums and minimums of precipitation were calculated, and for the calculation of their annual distribution the year is divided according to the identical in the case of water stream-flow principle, i.e. according to the hydrological seasons. 


\section{Results}

Table 2. Amount and peculiarities of the seasonal distribution of atmospheric precipitation of the meteorological stations of the North of the Russian Plain for the period from1995 to 2007

\begin{tabular}{|c|c|c|c|c|}
\hline & \multirow{2}{*}{ Meteorological station } & \multirow{2}{*}{ Annual amount of precipitation, $\mathrm{mm}$} & \multicolumn{2}{|c|}{ Seasonal distribution of precipitation (month), $\mathrm{mm}$} \\
\hline$\#$ & & & Maximum, $\mathrm{mm}$ & Minimum, mm \\
\hline 1 & Onega & $350-620$ & V-VII, VIII-X & II, IV \\
\hline 2 & Sura & $350-548$ & V-VII, VIII-X & XII-I, II- IV \\
\hline 3 & Syktyvkar & $409-576$ & VI-X, XI-XII & XII-I, II- IV \\
\hline 4 & Mudyug & $400-697$ & VII-IX & II, IV \\
\hline 5 & Vologda & $344-567$ & IV-V, VI-IX & I-III, XI-XII \\
\hline 6 & Ust-Vym & $358-492$ & V- VIIII, IX-X & II-III \\
\hline
\end{tabular}

Table 3. Long-term average annual value of the layer of stream-flow by hydrological stations of the North of the Russian Plain for the period from1995 to 2007

\begin{tabular}{|c|l|c|c|c|}
\hline \multirow{2}{*}{$\#$} & \multirow{2}{*}{ Hydrological station } & \multicolumn{3}{|c|}{ Long-term average annual value of the layer of stream-flow (h), mm, by hydrological } \\
\cline { 3 - 5 } & & \multicolumn{3}{|c|}{ seasons } \\
\hline 1 & Kena - Korovy Dvor & 75,5 & spring & summer-autumn \\
\hline 2 & Bol. Loptuga - Butkan & 41,8 & 109,2 & 154,9 \\
\hline 3 & Vesliana - Vozhael & 96,6 & 126,5 & 101,4 \\
\hline 4 & Kodina - Kodino & 47,7 & 156,1 & 149,0 \\
\hline 5 & Mudyuga - Patrakeevskaya & 81,6 & 132,4 & 159,5 \\
\hline 6 & Soyana - Soyana & 80,1 & 193,1 & 158,7 \\
\hline 7 & Syamzhena - Syamzha & 21,4 & 73,9 & 141,6 \\
\hline 8 & Dvinitza - Kotlaksa & 13,7 & 151,3 & 57,5 \\
\hline 9 & Sysola - Pervomaysky & 44,9 & 103,3 & 61,5 \\
\hline 10 & Vym - Vesliana & 42,2 & 118,3 & 131,2 \\
\hline 11 & Yarenga - Tokhta & 43,2 & 111,4 & 143,3 \\
\hline
\end{tabular}

Table 4. Dependence between precipitation and stream-flow for hydrological seasons for the period from1995 to 2007

\begin{tabular}{|c|c|c|c|}
\hline \# & Hydrological station & $\begin{array}{l}\text { Amount (r) of precipitation (winter-spring) / layer } \\
\text { of stream-flow (spring), mm }\end{array}$ & $\begin{array}{l}\text { Amount }(r) \text { of precipitation } \\
\text { (summer-autumn) / layer of stream-flow } \\
\text { (summer-autumn), } \mathrm{mm}\end{array}$ \\
\hline 1 & Yarenga - Tokhta & 0,71 & 0,59 \\
\hline 2 & Vym - Vesliana & 0,64 & 0,52 \\
\hline 3 & Sysola - Pervomaysky & 0,86 & 0,17 \\
\hline 4 & Syamzhena - Syamzha & 0,37 & 0,77 \\
\hline 5 & Soyana - Soyana & 0,12 & 0,78 \\
\hline 6 & $\begin{array}{l}\text { Mudyuga - } \\
\text { Patrakeevskaya }\end{array}$ & 0,15 & 0,81 \\
\hline 7 & Kodina-Kodino & 0,12 & 0,9 \\
\hline
\end{tabular}

Table 5. Distribution of hydro-meteorological parameters in the river basin of Onega in the summer-autumn hydrological season for the period from1995 to 2007 (on the example of the hydrological station Kodina - Kodino)

\begin{tabular}{|l|c|c|c|c|c|c|c|c|c|c|c|c|c|}
\hline \multirow{2}{*}{ Parameter } & \multicolumn{10}{|c|}{ Years } \\
\cline { 2 - 11 } & 1995 & 1996 & 1997 & 1998 & 1999 & 2000 & 2001 & 2002 & 2003 & 2004 & 2005 & 2006 & 2007 \\
\hline Layer of stream-flow, mm & 196,7 & 173,6 & 71,1 & 219,2 & 115,1 & 160,9 & 74,8 & 83,9 & 256,5 & 161,5 & 169,9 & 191,0 & 199,5 \\
\hline Amount of precipitation, mm & 384,0 & 314,8 & 190,9 & 403,1 & 290,6 & 288,8 & 211,3 & 286,2 & 418,2 & 312,4 & 277,9 & 382,1 & 389,9 \\
\hline
\end{tabular}


Table 6. Distribution of hydro-meteorological parameters in the river basin of Mezen in the summer-autumn hydrological season for the period from1995 to 2007 (on the example of the hydrological station Soyana - Soyana)

\begin{tabular}{|l|c|c|c|c|c|c|c|c|c|c|c|c|c|}
\hline \multirow{2}{*}{ Parameter } & \multicolumn{10}{|c|}{ Years } \\
\cline { 2 - 12 } & 1995 & 1996 & 1997 & 1998 & 1999 & 2000 & 2001 & 2002 & 2003 & 2004 & 2005 & 2006 & 2007 \\
\hline Layer of stream-flow, mm & 170,5 & 173,7 & 86,3 & 178,8 & 117,0 & 198,4 & 118,9 & 94,5 & 152,2 & 99,4 & 136 & 86,8 & 229,5 \\
\hline Amount of precipitation, mm & 374,4 & 334,4 & 215,6 & 481,5 & 303,7 & 258,1 & 203,4 & 204,6 & 326,2 & 280,8 & 284,8 & 211,9 & 501,7 \\
\hline
\end{tabular}

Table 7. Distribution of hydro-meteorological parameters in the river basin of Severnaya Dvina in the winter-spring hydrological season for the period from1995 to 2007 (on the example of the hydrological station Sysola - Pervomaysky)

\begin{tabular}{|l|c|c|c|c|c|c|c|c|c|c|c|c|c|}
\hline \multirow{2}{*}{ Parameter } & \multicolumn{10}{|c|}{ Years } \\
\cline { 2 - 11 } & 1995 & 1996 & 1997 & 1998 & 1999 & 2000 & 2001 & 2002 & 2003 & 2004 & 2005 & 2006 & 2007 \\
\hline Layer of stream-flow, mm & 85,2 & 35,0 & 200,9 & 87,0 & 110,1 & 132,6 & 149,4 & 107,3 & 123,9 & 119,9 & 142,9 & 69,5 & 174,7 \\
\hline Amount of precipitation, $\mathrm{mm}$ & 172,5 & 91,2 & 284,6 & 192,8 & 160,1 & 210,0 & 211,3 & 227,1 & 174,7 & 203,9 & 169,3 & 87,7 & 281,4 \\
\hline
\end{tabular}

\section{Discussion}

Long-term trends of annual precipitation in the region under studies are characterized by variability in the range of 350 $400 \mathrm{~mm}$ up to $550-700 \mathrm{~mm}$ (table 2). And during the period under consideration the largest share of precipitation was fixed by the MS of Onega and Mudyug (up to $700 \mathrm{~mm}$ ), which have the seaside location, and their fewest number - by MS of Ust-Vym. Over the last years we can observe the periods of increase and reduction of atmospheric precipitation in turns at all meteorological stations.

Annual distribution of atmospheric precipitation has definite maximums in May - July, August - October and minimums in December, February and April. In general, there is the predominance of precipitation of the summer-autumn period $(162-393 \mathrm{~mm})$ over the winter $(54-180 \mathrm{~mm})$ and spring $(31-219 \mathrm{~mm})$ seasons at all meteorological stations.

For the period from 1995 to 2007 the analysis of the dates of hydrological seasons at the selected gauging stations revealed the following trends. Depending on the location of the analyzed gauging stations, there is a slight displacement of the date of the beginning of the winter season, in some years falling on the end of October at some stations, but in the majority of cases it falls on the first or second decade of November. At all - without any exception - observation stations under studies the period of the middle of April - the beginning of May can be accepted as the so-called "hydrological" spring, and in these conditions the beginning of the summer-autumn period falls on the beginning-middle of May, in some years - the beginning of June.

Comparison of the dates of the beginning of hydrological seasons at different observation points shows the following. For example, at the gauging stations Yarenga-Tokhta and Vym-Veslyana with intra-state which are located intercontinentally and which are relatively close to each other, an earlier oncoming of the spring season is observed at the station Yarenga-Tokhta with a maximum difference of maximum 11 days. At the gauging station Sysola-Pervomayskiy which is located to the south from Yarenga-Tokhta, it was possible to record an earlier start (decade) of spring processes on rivers. On "the inland" station Syamzhena-Syamzha, also with respect to the station Yarenga-Tokhta, an earlier oncoming of spring with a difference of 15 days was observed.

In other hydrological seasons it is necessary to mention the following facts concerning the gauging stations under research: for example, a later start of the winter season for 28 (in 1999), maximum for 56 days (in 2001) days at the station Mudyuga-Patrakeevskaya in relation to the located slightly to the north station Zolotica-Verkhnyaya Zolotica. Later dates of the beginning of the "hydrological" winter in comparison with the station Yarenga-Tokhta during the period under consideration could be observed at the station Syamzhena-Syamzha with a difference of 33 - 35 calendar days.

Earlier dates of the beginning of the summer-autumn season - for 23 - 25 days - were observed during the analyzed period at the station Sysola-Pervomayskiy rather than at Yarenga-Tokhta. In general, comparison of the dates of the beginning of summer-autumn period at the stations Yarenga-Tokhta and Vym-Veslyana shows a slightly later start of the season at the first of them, although in some years this tendency was broken (in 1999 - 2000, 2002 - 2004).

Analysis of hydrological indicators at the selected stations of observation, such as the level and flow of water, allows to conclude that, for example, the spring-level rise and, consequently, an increase of river flow water, occurs at the beginning and - with the highest values - at the end of April-May. Thus, at the gauging station Vym - Veslyana the maximum flow rate were recorded on April, 24 - 25 and May, 10 reaching $1960-2020 \mathrm{~m}^{3} / \mathrm{s}$. Increase of river flow water in April and its highest values at this time are probably connected with the period of snow melt at the water storage basin 
(Agafonov, 2010).

In analyzing the river flow layer its seasonal changes, which show a trend for increase in the spring and summerautumn seasons, are the most significant ones. At the same time, it is possible to distinguish gauging stations at which during the period under consideration there was predominace of the share of spring runoff over the summer-autumn one, in particular, Bolshaya Loptyuga - Butkan, Mudyug - Patrakeevskaya, Syamzhena - Syamzha, Yarenga - Tokhta (table 3). The analysis of the distribution of the amount of the river flow layer by the stations in the winter season allows us to speak about its greatest value at the gauging stationsVeslyana - Vozhael, Mudyug - Patrakeevskaya, Soyana - Soyana, where the average annual rate $h$ was in the range of $80-97 \mathrm{~mm}$, and its smallest value was at the station Dvinitsa Kotlaksa - $13.7 \mathrm{~mm}$ in the period from 1995 to 2007.

In the spring period, as with the case of the winter runoff, the values were large Photo for the stations Mudyug Patrakeevskaya, Veslyana - Vozhael, Yarenga - Tokhta (160 - $193 \mathrm{~mm})$, with minimum values at the station Soyana Soyana $(74 \mathrm{~mm})$. Finally, in the summer-autumn hydrological season during the analyzed period the largest values of $\mathrm{h}-$ about $160 \mathrm{~mm}$ - were recorded at the gauging stations Kodina - Kodino, Kena - Koroviy Dvor, Mudyuga Patrakeevskaya, and the minimum values - 57 - 60mm - at the gauging stations Syamzhena - Syamzha, Dvinitsa Kotlaksa.

Relationship between atmospheric precipitation and the river flow layer by hydrological seasons were identified during the research study. In particular, the closest connection was established between atmospheric precipitation and runoff of the summer-autumn period where the correlation coefficient $(r)$ for the stations Soyana - Soyana, Mudyuga Patrakeevskaya $r=0,7-0,8$, reaching $r=0,9$ (Kodina - Kodino). Comparison of precipitation of the winter- spring period with the spring run-off did not reveal such close connection, with exception of the station Sysola - Pervomayskiy (the basin of the Northern Dvina), where $r=0,86$ (table 4).

It is mentioned that by the annual period there are two maxima and two minima in distribution of atmospheric precipitation, while they do not fully coincide in time with atmospheric precipitation in overland runoff. Synchronous increase of the share of atmospheric precipitation and the runoff are recorded from May to July and in October, with exception of August (precipitation) and April (runoff), where these periods do not coincide. The least amount of precipitation was in December, February, and this accordingly reflected on the rate of the stream flow. However, the decrease of runoff was also during the period from August to September, contrasted to the increase of atmospheric fall at this time. Decrease of the flow was clearly recorded in this period, for example, by the stations Mudyuga Patrakeevskaya, Dvinitsa - Kotlaksa.

When examining the connection "precipitation - runoff" for some gauging stations for the period from 1995 to 2007, we can generally say about synchronous increase (decrease) of these indicators. But, in some years, such connection was asynchronous in nature and, for example, at the stations Kodina - Kodina, Soyana - Soyna, Sysola - Pevomajskij asynchrony in the form "reduction of precipitation - increase of runoff" and vice versa was observed in 1996, 1999, 2000, 2002 - 2004 (tables 5,6,7).

асинхронность в виде уменьшение осадков - увеличение стока и наоборот наблюдалась в 1996, 1999, 2000, 2002 - 2004 гг. (табл. 5,6,7).

\section{Conclusion}

The river run-off, which is the result of interaction of the climatic factor and physical-geographic conditions of the river basin, is the main source of water resources (Muraschenkova, 2007). Occurring in the last decade climate change, which is mostly manifested in the change of the regime of atmospheric precipitation and other meteorological parameters, greatly influence the change of the hydrological regime of water bodies (Moritz et al ,. 2002).

In this work the review and analysis of the main hydrological indicators, mainly runoff and atmospheric precipitation, their interconnection and spatial-temporal variability was made on the example of the region of the North of the Russian Plain. The subject region is characterized by extensive river network, about 138000 rivers with a total length of $521200 \mathrm{~km}$, belonging to the basins of the Northern Dvina, Pechora, Onega, Mezen.

The aim of our study was mainly to establish connection between precipitation and runoff, as well as to identify patterns of spatial-temporal changes of the river runoff and atmospheric precipitation in the subject region. To achieve this goal of the work the atmospheric precipitation and water flow rate data obtained from the site of the All-Russian Research Institute of Hydro-meteorological Information - World Data Center (Obninsk) and Sevgidromet (Arkhangelsk) was used. The presence and work with the material allowed to make calculations of the amount and the run-off layer rates, as well as the amount of atmospheric precipitation in seasons and annually, with the subsequent analysis of the results obtained. 
The analysis results of the work done are the following. On the territory of the region the annual precipitation is variable, ranging from $350-400$ to $550-700 \mathrm{~mm}$. At all meteorological stations of the territory under study there is predominance of precipitation of the summer-autumn period over the winter and spring periods. Besides, depending on the location of hydrological stations the change of the date of the beginning of the winter season, in some years falling on the end of October at some stations, and in the majority of the stations - on the first or second decade of November, was identified. Spring processes on the rivers of the region fall on the beginning of months, reaching maximum at the end of April - May. For example, at the hydrological station Vym - Veslyana the maximum flow rates were recorded on April, 24 - 25 and May, 10, reaching the value of $1960-2020 \mathrm{~m}^{3} / \mathrm{s}$.

The amount of the run-off layer shows the tendency for increase in the spring and summer-autumn seasons. At the same time, for example, at the gauging stations Bolshaya Loptyuga - Butkan, Mudyuga - Patrakeevskaya, Syamzhena Syamzha, Yarenga - Tokhta there is the dominance of the share of the spring runoff over the summer-autumn one. Besides, the connection between atmospheric precipitation and runoff was established, and the closest dependence between the parameters is observed in the summer-autumn period, when the correlation coefficient $(r)$ for the stations Soyana - Soyana, Mudyuga - Patrakeevskaya is $r=0,7-0,8$, reaching $r=0,9$ (Kodina - Kodina). Dependence of precipitation of the winter-spring period with the spring run-off did not reveal such close connection. Synchronous increase of the share of precipitation and runoff was observed from May to July and in October, with the exception of August (precipitation) and April (run-off), when these periods do not coincide. When examining the connection "precipitation - runoff" for some gauging stations for the period from 1995 to 2007, we can generally say about synchronous increase (decrease) of these parameters. But in some years such connection was asynchronous in nature and, for example, for the stations Kodina - Kodino, Soyana - Soyana, Sysola - Pervomayskiy asynchrony in the form "decrease of precipitation - increase of runoff "and vice versa was observed in 1996, 1999, 2000, 2002 - 2004.

\section{Statements}

1. in the long-term period of several years the amount of precipitation on the territory under study is rather variable, and it is in the range from 350 to $700 \mathrm{~mm}$.

2. The starting date of the so-called "hydrological" winter on the territory of the North of the Russian Plain are different at different gauging stations. For example, the difference in the dates of the beginning of the season is from 28 to 56 calendar days between relatively closely located observation stations Mudyuga Patrakeevskaya and Zolotica - Verkhnyaya Zolotica.

3. Connection between atmospheric precipitation and run-off layer is the closest in the summer-autumn hydrological season, when at some stations, for example, Kodina - Kodina, the correlation coefficient reaches 0.9. In other hydrological seasons such close connection between the analyzed parameters is not observed.

4. In annual terms in the distribution of atmospheric precipitation two maxima and two minima are stood out, while in the overland run-off they do not coincide with atmospheric precipitation in time. Synchronous increase of the share of atmospheric precipitation and the run-off was observed from May to July and in October, with the exception of August (precipitation) and April (run-off), when these periods do not coincide.

\section{Ackonwledgement}

The authors of the article express their deep appreciation and gratitude to the staff of the Department of Landscape Ecology of the Kazan Federal University for providing original materials and carried out consultations concerning the content of the subjects of the research study.

\section{References}

Agafonov, L.I Stok Nizhney Obi i ego izmenenie v XX stoletii // Izvestiya RAN. Seriya Geograficheskaya, vyip. 4. - M., 2010. - s. 68 76.

Musaelyan, S.M. O mnogoletnih tsiklicheskih kolebaniyah godovogo stoka reki Volgi u goroda Volgograda // Povolzhskiy ekologicheskiy vestnik, vyip. 9. - Volgograd, 2002. - s. 35 - 43.

Filenko, R.A. Gidrologicheskoe rayonirovanie severa Evropeyskoy chasti SSSR. - L.: izd-vo Leningr. un-ta, 1974. - 223 s.

Berezovskaya, S., D. Yang and D. Kane, 2004. Compatibility analysis of precipitation and runoff over the large Siberian watersheds. Geophys. Res. Letters.V. 31. L21502, doi:10.1029/2004GL021277.

Moritz, R., C. Bitz and E. J. Steig, 2002. Dynamics of recent climate change in the Arctic. Science. V. 297.P. 1497-1502.

Shiklomanov, A., R. Lammers, M. Rawlins, L. Smith and T.M. Pavelsky, 2007. Temporal and spatial variations in maximum river 
discharge from a new Russian data set // J. Geophys. Res. V. 112. G04S53, doi:10.1029/2006JG000352.

Smith, L., T. Pavelsky, G. MacDonald, A. Shiklomanov and R.B. Lammers, 2007. Rising minimum daily flow in northern Eurasian rivers: A growing influence of groundwater in the high-latitude hydrological cycle // J. Geophys. Res. V. 112. G04S47, doi:10.1029/2006JG000327.

Smirnova E.V., Urazmetov I.A. Ecological state of water and soil of natural-anthropogenic landscapes in the oil-producing regions. Mediterranean Journal of Social Sciences.- Vol.5, No18, (2014)-pp.367-372.

Urazmetov, I.A., Smirnova, E.V., Kadyrova, R.G. Features of the soil of subboreal semihumid landscape zone within urbanized areas. Mediterranean Journal of Social Sciences, 5 (18 SPEC. ISSUE), pp. 373-377.

Surd, V., I. Kassai and L. Giurgiu, 2011. Romania disparities in regional development. Proceedings of the 2nd International Geography Symposium-Mediterranean Environment, JUN. 02-05, 2010, Antalya, Turkey. Book Series: Procedia Social and Behavioral Sciences (19), pp: 21-30. DOI: 10.1016/j.sbspro.2011.05.102.

Vardomsky, L.B., 2001. Russia in the context of external policy: Regionalization problems in the context of regional process dynamics. In Regionalization in the development of Russia. Geographical processes and problems. Russian Academy of Sciences: Institute of Geography press, pp: 67-86.

Wokoun, R, 2009. Regional Competitiveness And Regional Development Factors In The Czech Republic. Proceedings of the: 3rd Central European Conference in Regional Science, OCT. 07-09 Kosice, Slovakia, pp: 893-900.

Nurieva A.R., Gibadullin M.Z., Fazlieva E.P. Stability of Interregional Trade and Economic Relations as the Factor of Competitiveness of Territories // World Applied Sciences Journal 29 (4), 2014, pp. 501 - 505.

Bulatov A.N., Mukhametshina G.R., Gazizullina A.R., Toropova N.V. The Role of the Project "Enterprise Factory" in the Competitiveness Recovery of the Regional Economy of the Republic of Tatarstan// Mediterranean Journal of Social Sciences.- Vol.5, No12, (2014)-pp.141 - 144 